\title{
NELFCD Gene
}

National Cancer Institute

\section{Source}

National Cancer Institute. NELFCD Gene. NCI Thesaurus. Code C105097.

This gene is involved in the negative regulation of transcript elongation. 